\title{
Analysis of Restructuring Strategy Of PT Indofood Sukses Makmur Tbk in Developing Company Life
}

\author{
Mochammad Ridwan Ristyawan* \\ Universitas Tanjungpura
}

\begin{abstract}
ABSTRAK
PT Indofood Sukses Makmur, Tbk. melakukan restructuring dengan memisahkan divisi Mi Instan dan Consumer Branded Product menjadi perusahaan baru yang bernama PT Indofood Consumer Branded Product, Tbk. Restructuring Indofood bertujuan untuk untuk mencapai efektivitas kinerja operasional Indofood dan meningkatkan value perusahaan. Kondisi internal dan perubahan lingkungan eksternal perusahaan mendorong Indofood melakukan restructuring. Penelitian ini menganalisis tentang faktor-faktor lingkungan internal dan eksternal perusahaan yang mempengaruhi Indofood melakukan restructuring. Analisis restructuring strategy Indofood terdiri atas empat tahapan, yaitu: analisis kinerja Indofood sebelum restructuring, analisis kinerja Indofood setelah restructuring, analisis wealth effect shareholder dan value building growth dan analisis kinerja jangka panjang korporat. Kinerja Indofood sebelum restructuring menunjukkan efisiensi biaya tetapi belum mampu menghasilkan laba bersih operasional yang tinggi jika dibandingkan dengan kinerja industri food and beverages. Restructuring Indofood telah berhasil meningkatkan nilai perusahaan yang sangat tinggi. Peningkatan nilai perusahaan tidak memberi kemakmuran bagi para pemegang saham dan tidak sebanding dengan pertumbuhan perusahaan dalam waktu jangka panjang. Indofood memerlukan strategi-strategi baru untuk tetap dapat meningkatkan penjualannya agar sebanding dengan peningkatan nilai perusahaan. Strategi pemasaran harus diperbaharui untuk mengintensifkan peningkatan penjualan pada level fungsional yang didukung oleh procurement, human resources dan infrastruktur IT yang baik.
\end{abstract}

Kata kunci: restructuring, nilai perusahaan, pertumbuhan perusahaan

\section{INTRODUCTION}

\subsection{Background}

Unsatisfactory corporate performance shown by Indofood's net sales in 2009 amounted to 37.4 trillion rupiah lower than in 2008 of 38.8 trillion rupiah (Indofood Annual Report, 2010). These conditions make Indofood take strategic steps to conduct an internal restructuring to overcome the problems of the company.

\footnotetext{
* Korespondensi: Mochammad Ridwan Ristyawan, Jurusan Manajemen, Fakultas Ekonomi dan Bisnis, Universitas Tanjungpura, Jalan Prof. DR. H. Hadari Nawawi, Pontianak 78124, Indonesia. Email: $\underline{\text { m.ridwanristyawan@untan.ac.id }}$
} 
Indofood Resctructuring was done by separating the Division of Consumer Branded Products (CBP) into a separate business entity. The new company's 99.9 percent was owned by PT Indofood, Tbk operating effectively in early 2010. Increasing the value of the company's restructuring process is an effort to encourage the growth of the company. Indofood growth is expected by the shareholders so as to increase its prosperity. At worst it can also occur when there is an increase in the value of the company but is not balanced by the growth of the company.

High expectations of the shareholders of the company did not follow the high growth of the company and will lower the return on long-term corporate value. Restructuring objectives are not only to address short-term problems associated with the company but should be in the company's long-term solution to maintain growth. This study will analyze the impact of divested businesses from internal restructuring process towards sustainability of Indofood and corporate focus.

Indofood's restructuring is an effort to increase the value so that the company's expected continued growth can be maintained in the future. Based on the above background, The objectives of this research are to identify the condition of the company's performance before restructuring occurs which Indofood's driving force in restructuring, to analyze the magnitude of the synergy achieved by the management of Indofood and Indofood profits as a result of restructuring based on the value of the company, to analyze the impact of restructuring on the shareholders wealth and to analyze the impact of the Indofood divestment strategy which is corporate restructuring to focus in the long run.

\section{LITERATURE REVIEW}

Thompson et al. (2010) defines a company's strategy to be shaped partly by management analysis and choice, and partly by necessity of adapting and learning by doing. Changing circumstances and ongoing management needs efforts to improve the strategy, cause a company's strategy to evolve overtime - a condition that makes crafting a strategy for a process, not a one-time event.

Each company must be prepared to modify its strategy in the face of changing market conditions, technological developments, movement of the competitors, the shift in buyers' needs and preferences, emerging market opportunities, new ideas, and the findings of the failure of strategy.

Conditions of company performance became the basis of a corporate restructuring to do. Donald et al. (2007) believe that managers will conduct refocus, eliminating negative synergies, and improve cash as an effort to generate the highest 
financial returns. Company's performance will be seen from the level of profit generated company growth and value of corporate assets from year to year.

Corporate restructuring is the company's strategy to reshape the corporate structure including the Design, Execution, and Marketing, which aims to enhance corporate value. Design is the process of selecting the appropriate type of restructuring with the problems encountered and the desired opportunity of the company.

The value of synergies resulting from the restructuring of the company is the difference between the value of the company before and after restructuring. The value of synergy is the result of the efficiency of restructuring carried out management or expansion of the company so that company growth can be maintained.

Restructuring strategy aims to enhance corporate value as reflected in rising stock prices in the market. Company's value will be calculated by several steps, namely:

1. Cost of Capital Calculation

2. Discounted Cash Flow (DCF)

3. DCF Spreadsheet Valuation

Weston et al. (2004) suggests that the wealth effect resulting from the restructuring of the company will be enjoyed by the shareholder as a result of rising stock prices. The increase in stock prices in response to positive abnormal returns that occur at the time of restructuring carried out.

Kearney (1999) in Baskoro (2009) states that the creation of value for shareholders by focusing on the growth of profit can be said to be a profit trap that can create value for shareholders in the short term, but fails to exploit the potential of corporate organization to create value for shareholders in the long term.

AT Kearney Growth Matrix category consists of four, namely: Value Growers (high-growth companies value comparable with the high revenue growth companies), Profit Seekers (the growth of corporate value is higher than revenue growth companies), Simple Growers (enterprise value minus growth while the growth high-revenue companies), Underperformers (enterprise value minus growth while the company's revenue growth is very low).

\section{RESEARCH METHOD}

This study is an exploratory descriptive study that explains the factors driving PT Indofood, Tbk restructuring strategy which aims to improve corporate value. Research used secondary data obtained from the Annual Report of PT Indofood, Annual Report of 
PT Indofood Consumer Branded Product, Share Price Data of PT Indofood, and PT Indofood Consumer Branded Products, listed on the Indonesia Stock Exchange, Press releases on the Internet web, web articles and previous research data.

The research was conducted through the research phase which consists of four sections, covering:

1. Performance Analysis of Indofood before Restructuring.

2. Synergy Value and Profitability Analysis of Indofood's Restructuring.

3. Analysis of Shareholders Wealth.

4. Analysis of Long-Term Corporate Performance.

\section{RESULTS AND DISCUSSION}

Analysis of this study used several macro-economic assumptions and micro economics. Macroeconomic conditions in food and beverages industry is divided into three based on historical data, Indofood Financial Report 2003 to the year 2008 as good, moderate and bad. Whereas, micro-economic assumptions are based on the internal condition of Indofood. Indofood internal conditions are known to identify the financial performance prior to restructuring of Indofood, i.e. from 2003 through 2008.

Analysis of Indofood's restructuring strategy consists of four stages: analysis of Indofood's performance prior to restructuring, the analysis of the value of synergies and restructuring benefits Indofood, the analysis of the prosperity of the shareholders, and the analysis of long-term corporate performance.

Analysis of Indofood's performance before restructuring aims to determine the comparative growth of Indofood to the growth of food and beverage industry (Food and Beverages). Comparison of the growth of Indofood and Industrial food and beverages before the restructuring is done by calculating the ratio of COGS / sales, SG \& A / sales, NOI / sales, sales / assets and the NOI / assets from 2003 to 2008. Calculation of ratio values was derived from data of Indofood's Financial Statements from 2003 to 2008.

Measurement of the value of synergies and benefits resulting from the restructuring of Indofood was done by calculating the value of the company before and after the restructuring then compare the two to obtain the value of synergies. There are three stages of calculating the value of the company namely: Cost of Capital Calculation, Discounted Cash Flow (DCF) and DCF Spreadsheet Valuation.

Assessment of the company was tested with 2 tests of Sensitivity Analysis and Performance Test of Restructuring. Matrix sensitivity analysis shown in Table 1. 
Table1. Indofood's Sensitivity Analysis Matrix

\begin{tabular}{|c|c|c|c|c|}
\hline \multirow[b]{2}{*}{ Cost of Capital } & \multicolumn{4}{|c|}{ Number of Years of Competitive Advantage } \\
\hline & 2 & 6 & 8 & 14 \\
\hline $7 \%$ & $4.903,98$ & $5.278,47$ & $5.897,21$ & $7.387,78$ \\
\hline $9,16 \%$ & $4.826,25$ & $5.226,64$ & $5.457,36$ & $6.297,44$ \\
\hline $14,00 \%$ & $4.667,86$ & $5.130,64$ & $4.713,41$ & $4.760,15$ \\
\hline $19,98 \%$ & $4.498,01$ & $5.041,08$ & $4.111,51$ & $3.819,71$ \\
\hline
\end{tabular}

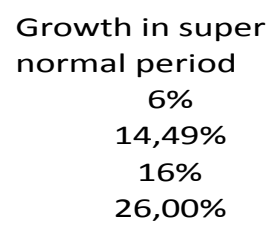

Net Operating Income Margin
\begin{tabular}{|r|r|r|r|}
\hline $3 \%$ & $17,52 \%$ & $23 \%$ & $41 \%$ \\
\hline $4.601,16$ & $4.350,55$ & $4.255,96$ & $3.945,29$ \\
\hline $4.751,17$ & $5.226,64$ & $5.406,09$ & $5.995,52$ \\
\hline $4.781,77$ & $5.405,35$ & $5.640,69$ & $6.413,71$ \\
\hline $5.020,91$ & $6.801,89$ & $7.474,05$ & $9.681,88$ \\
\hline
\end{tabular}

Test of Restructuring Performance for Indofood is as follows:

$\begin{array}{llll}\text { Company value after restructuring } & = & 55.144 .991,00 \\ \text { Company value before restructuring } & = & (7.910 .109,84) \\ \text { Benefits from restructuring } & = & 47.234 .881,16\end{array}$

Value of Indofood profits from restructuring has been done of $\operatorname{Rp} 47,234,881.16$ (in millions of dollars). Increasing the value of Indofood company is extremely high because after the restructuring the flow of cash coming from multiplying Indofood gained from the sale of shares of its subsidiary PT ICBP to the public through an IPO on the Indonesia Stock Exchange during the year 2010.

Shareholders Wealth Effect Analysis and Value Building Growth into Indofood restructuring policy evaluation tool to find prosperity obtained by the shareholders and the comparison of the resulting increase in corporate value of the company's revenue growth.

The prosperity of the shareholders of Indofood was obtained from the intrinsic value per share amounting to 4288.82 rupiah. Increasing prosperity is generated from the value of synergy restructuring of Indofood divided by the number of outstanding shares. Indofood shareholders enjoy added prosperity from the restructuring of Indofood.

Indofood Company's value grew enterprise value of $159.97 \%$ and revenue growth of gross sales shown Indofood increased by 2.69\% from year 2009 until 2010. Increasing the value of the company was shown to be very high and revenue growth that is not too high so Indofood, by AT Kearney Growth Matrix was categorized into profit seekers. 
Indofood revenue growth of $18.41 \%$ in 2010 will raise the value of the company as reflected in the increase in the price per share intrinsic. Indofood cost efficiency levels better than the food and beverages industry, but the ability to generate corporate profits are still below the food and beverages industry.

Indofood must be able to keep the increase in firm value obtained from the process of restructuring to improve its performance in maintaining revenue growth and improving corporate earnings growth is the key to the company. New strategies are needed by Indofood to intensify the increase in sales for the company to continue to grow and expand in the future.

\section{CONCLUSION AND RECOMMENDATIONS}

Indofood's restructuring based on the analysis of four stages above can be summarized as follows. First, Indofood adopted a policy of restructuring strategy driven by the internal condition of the company. Second, Indofood restructuring policies are needed to obtain cash inflow thereby increasing corporate value by increasing free cash flow. Third, increasing the value of the company to give prosperity for our shareholders. Finally, increasing the value of Indofood is not worth the company's growth in the long run.

Based on the conclusion of the analysis of Indofood in increasing the value restructuring (value) firms, it can be suggested as follows. First, Indofood efficiency levels that are good must be balanced with the ability of Indofood in generating profits. Second, high value of the company should originate company's operational performance in generating profits. Third, wealth of shareholders are enjoyed not only in the form of increased market share price and dividend of Indofood alone but derived from revenue growth, increased NOI and cost efficiency. Finally, Indofood require new strategies to continue to increase its sales to be comparable to the increase in firm value.

\section{REFERENCES}

Anslinger, P. L. Klepper., Steven J., and Subramaniam, S. (1999). Breaking Up Is Good To Do. The McKinsey Quarterly. pp. 16-27

Cao, B. Jiang, B. \& Koller, T. (2011). Sustaining top-line growth: The real picture. McKinsey Quarterly. Retrieved from http://www.mckinsey.com/businessfunctions/strategy-and-corporate-finance/our-insights/sustaining-top-linegrowth-the-real-picture. 
Copeland, T. E., Lembgruber, E. F \& Mayers, D. (1987). Corporate Spinoffs: Multiple Announcement and Ex-Date Abnormal Performance. in T. E. Copeland (Eds). Modern Finance and Industrial Economics. New York: Basil Blackwell.

Dobbs, R., Goedhart, M., and Suonio, M. (2007). Are Companies getting better at M\&A? Retrieved from http://pages.stern.nyu.edu/ igiddy/articles/better_mergers.pdf

Gayatri. (2011). Menteri Perindustrian Harapkan Industri Makanan dan Minuman Tumbuh . Retrieved from http://www.mediaindonesia.com August 23th 2011.

Gillan, S. L., Kensinger, J. W. \& Martin, J. D. (2000). Value creation and corporate diversification: the case of Sears, Roebuck \& Co. Journal of Financial Economics, 55(1), 103-137

Gilson, S. (2001). How To Make Restructuring Work for Your Company. Retrived from http://hbswk.hbs.edu/item/2476.html.

Hite, G. L. \& James, E. O. (1983). Security Price Reactions Around Corporate Spin-Off Announcements. Journal of Financial Economics, 12(4), 409-436.

Kaplan, R. S., \& Norton, D. P. (2006). How to Implement a New Strategy Without Disrupting Your Organization. Harvard Busines Review, March, 100-109.

Klein, A., Rosenfeld, J. \& Beranek, W. (1991). The Two Stages of an Equity Carve-Out and the Price Response of Parent and Subsidiary Stock. Managerial and Decision Economics, 12(6), 449-460.

Mavlutova, I. (2008). Restructuring of Business As A Way Of Increasing A Company's Value. Department of Finances, BA School of Business and Finance, Riga, Latvia.

Michaely, R. \& Shaw, W. H. (1995). The Choice of Going Public: Spin-Offs vs. CarveOuts. Financial Management, 24(3), 5-21.

Monalisa and Fitra, S. (2011). Target Pertumbuhan Pendapatan Indofood Realistis. Retrived from www.indonesiafinancetoday.com.

Schipper, K. \& Smith, A. (1983). Effect of Recontracting on Shareholder Wealth. Journal of Financial Economics, 12(4), 437-467. 
Schipper, K. \& Smith, A. (1986). A Comparison of Equity Carve-Outs and Equity Offerings: Share Price Effects and Corporate Restructuring. Journal of Financial Economics. 15(1-2), 153-186.

Weston, F. J., Mitchell, M. L. \& Mulherin, H. J. (2004). Takeovers, Restructuring and Corporate Governance (4th Ed). Upper Saddle River. N.J.: Pearson Education.

Wibowo, A. T. (2009). Indofood Pisahkan Divisi Mi Instan. Retrived from www.vivanews.com.

Wibowo, A. T. (2011a). Equity Carve-Outs. Retrived from http://macabus.com/ restructuring/equity-carve-outs.

Wibowo, A. T. (2011b). Spin- Offs and Split- Offs. Retrived from http://macabus.com/ restructuring/spin-offs. 